\title{
THE TRACK RECORD OF USD STUDENT ORGANIZATIONS: A YOUNG DRIYARKARA CREATIVITY REVOLUTION
}

\author{
Intan Printina Brigida \\ Sanata Dharma University, Indonesia \\ brigidaintan91@gmail.com \\ DOI: https://doi.org/10.24071/ijhs.2018.010211
}

received 8 September 2017; revised 19 January 2018; accepted 21 February 2018

\begin{abstract}
This article describes the track record of student organizations (UKM) at Sanata Dharma University (SDU). This study tried to reveal the contribution of student organizations as a creativity revolution especially for students' personality development, which will lead to the progress of SDU. The research type was a descriptive qualitative research which aims to elaborate the history of student organizations in SDU based on the viewpoint and spirit of young Driyarkara. The method of the research were interviewing, gathering data, and analyzing results. The result of this study indicated that student organizations in SDU have contributed to improve students' personality developments such as mental and physical development, cognitive and social development, public speaking and also vocal skill. Thus, the students are not only competent in hard skills but also soft skills which prioritize human values.
\end{abstract}

Keywords: track record, student activity units, creativity, young driyarkara revolution

\section{Introduction}

A student organization is one of the distinctive features owned by academic society of Sanata Dharma University (SDU) outside their curricular activities (academic activities) and co-curricular activities (freshmen personality development program-- $P P K M B$ ). Thus, student organizations are extracurricular activities which enrich their creative talents and help develop their personalities.

Student organizations (Unit Kegiatan Mahasiswa-UKM) or commonly known as a campus activities community is a place where students can engage in multiple interests and channel their hobbies, ideas, aspirations and energy to make the most of their time. UKM is considered as a means to enhance their soft skills.

This is in line with the rules of Kemendikbud RI (Indonesia's Ministry of Education and Culture) No.155/U/1998 about Student Organization General Guidelines (Pedoman Umum Organisasi Kemahasiswaan) in universities which stated that intra-college student organizations is a vehicle and means of student self-development toward the expansion of insights, increased their scholarly quality and integrity to achieve the goal of higher education. 
UKMs in Sanata Dharma University have given birth to excellent individuals proven with various achievements which will be discussed in this research. However, one limitation is identified from many UKMs in Sanata Dharma University which is their track record. Sanata Dharma University has recorded only small number of achievements of the whole bunch of student organizations whose activities and progress are unknown by many people including students.

There are some related studies being reviewed in this study especially those related to UKMs' track record. The review of related studies provide several theories, such as, theory of UKMs, creativity, and the principle of Driyarkara on humanizing young human.

The purpose of student organizations is to promote intentional involvement, facilitate leadership, and encourage student growth by interacting with various identities that distinguishes them from other groups. This opportunity help develop the cohesiveness between groups. Cohesiveness between groups is defined as an agreement of the members in achieving their objectives and mutual acceptance among the members of the group (Munkitar, 2008). The more engaged they are to the objectives, the closer they get as team members.

According to Munkitar (1985), creativity is the ability to create new combination, based on existing data, information or the elements. The results created are not always new things, but can also be combination from the existing things. In addition, Csikszentmihalyi (in Clegg, 2008) states that creativity is an action, ideas, or products that change something obsolete becomes something new. Creativity is one of the basic needs of human being, which is the need of self-actualization which is the highest stage in human needs' hierarchy (Maslow, in Munkitar, 2009). Basically, everyone was born with their innate creative potential. Creativity can be identified and nurtured through proper education (Munkitar, 2009). According to the NACCCE (National Advisory Committee on Creative and Cultural Education) (in Craft, 2005), creativity is imaginative activity which produces valuable new results. Furthermore, Feldman (in Craft, 2005) defines creativity is: "the achievement of something remarkable and new, something which transforms and changes a field of endeavor in a significant way. . . the kinds of things that people do that change the world." While according to Rogers (in Zulkarnain, 2002), creativity is human tendency to actualize themselves in a manner conforming with their own ability. From that sense, creativity is one of the essential elements in students activities in order to enhance their personality development and to actualize their potential so they will feel themselves more meaningful and valuable.

There is a thought that simply uplifts every human being over an understanding that Driyarkara's thoughts contradict the opinion of a philosopher, Thomas Hobbes with his statement "Homo Homini Lupus", which means man is a wolf to other human beings. While Driyarkara has a new notion of "Homo Homini Socius", which means man is a friend for others. He tried to put his thinking as the foundation of the new human education, in order for humans to become more aware of their existence as the subject of all material in the world without neglecting their neighbors (Wardaya, 2009).

Driyarkara's concept can represent various kinds of problems. Driyarkara combines his theological concept with Malebranche's view to formulate the goal 
of human existence. His views are influenced by Heidegger's view of existence and the Javanese philosophy. Driyarkara agrees the problem of existence as a central theme that connects all other human activities. Human consciousness includes being aware of their existence and also aware of their purpose of existing. It is what spreads in Driyarkara discussion room when commenting on other realm of activities such as social, human, culture and also education. He thinks that men who exist are able to realize the purpose of his life, what potential he can produce, and what he should do. The more interactions generated and resulting in a uniform routine will potentially lead to several new discoveries as humans attempt to conquer nature.

\section{Method}

The track record of UKMs in USD as a means to channel students' creativity, which is also in line with SDU' Motto "Intelligent and Humanist", was studied using the descriptive qualitative method by conducting interview or oral history study.

The data were in the form of collected documents and oral sources conducted by interviewing in Sanata Dharma University's UKMs and supported by the researchers' observation. Sutopo (2006, p.139) states that qualitative research always presents its findings in the form of detailed, complete, and profound description of the process on why and how things happen. Using descriptive qualitative research, researchers was able to capture the qualitative description with detail information (Sutopo, 2006, p.227). Research report showed the data from various sources to answer the research problem.

Data analysis technique used in this research was inductive approach. The process and meaning were highlighted in qualitative research or in historical study. Oral history research is data collection in the form of photo documents and other documents based on the formulation of the problem in this study. Therefore, this research required two observers to collect data and researchers to analyze data.

\section{Findings and Discussion}

The discussion of the track records of student organizations will be divided based on the organizations' contribution to the development of student's personality which is in line with Driyarkara's notion "Humanizing young human". The contributions are mental and physical development, cognitive and social development, public speaking and also vocal training. Student organizations of SDU that can hone mental personality and work the body among others are Grisadha, Mapashada, Tutu Club, Karawitan, Football, Menwa, TSD, Aikido, Basketball, INKAI, KEMPO, and Taekwondo.

Resembling praying, dancing is the soul and spirit of Grisadha, so the two are inseparable, because the soul and the spirit form an art. Dancing has been considered as some kind of a dialogue with The God Almighty. There are also performances that have been wrapped up gracefully by Grisadha like the performances Tangkuban Perahu (2007), Dewi Sri (2008), Tangkuban Perahu Part 2 (2009). As time goes by, Grisadha is increasingly acknowledged as a student organization with a lot of potential. Other than that, in 2010 Grisadha participated in a regional level competition (selekda). 


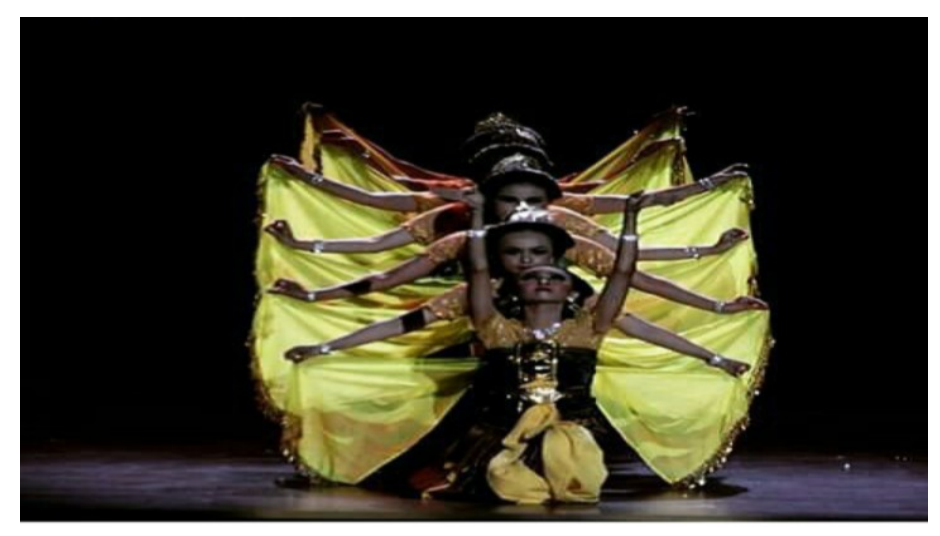

Figure 1: Roro Mendut Performance in October 16, 2015

Source : Grisadha Student Organization

MAPASADHA is a student organization in SDU which has stood since October 18, 1981 concerning environmental group. In its 32 years of operating, there are a lot of activities that have been carried out by MAPASADHA. There are routine activities like MAPASADHA Anniversary, dikjut (further education), and regeneration. Furthermore, there are also other activities like earth day celebration and expedition. Activities in open nature can be dangerous, so it needs careful planning. Management includes Planning, Organizing, Actuating, and Controlling.

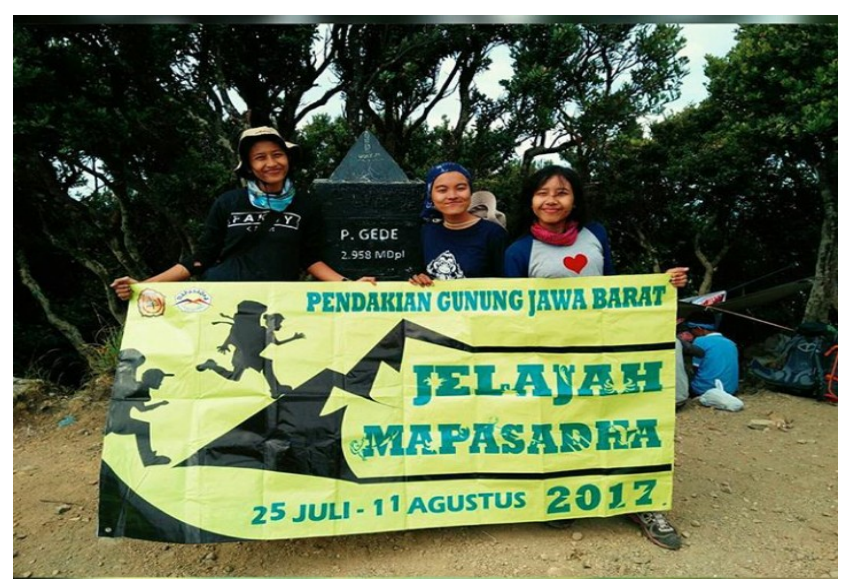

Figure 2: MAPASADHA expedition-Gede Pangrango Mountain 2017

Source: MAPASADHA Student Organization

TUTU (To Universe That Utopia) means 'to the world that believes in dreams more than anything'. Fitting with its philosophical meaning, ballet student organization, TUTU Club, defines itself as an organization which is formed because of the common dreams or hopes of SDU students who have interest and talent in the field of ballet. TUTU Club was officially appointed as a student organization on October 21, 2011. The objective of TUTU Club is to be a place where students who love and wanted to develop themselves in the art of ballet and 
to hone their organizational abilities in the field of student organization management as well as being a committee of internal events or public events.

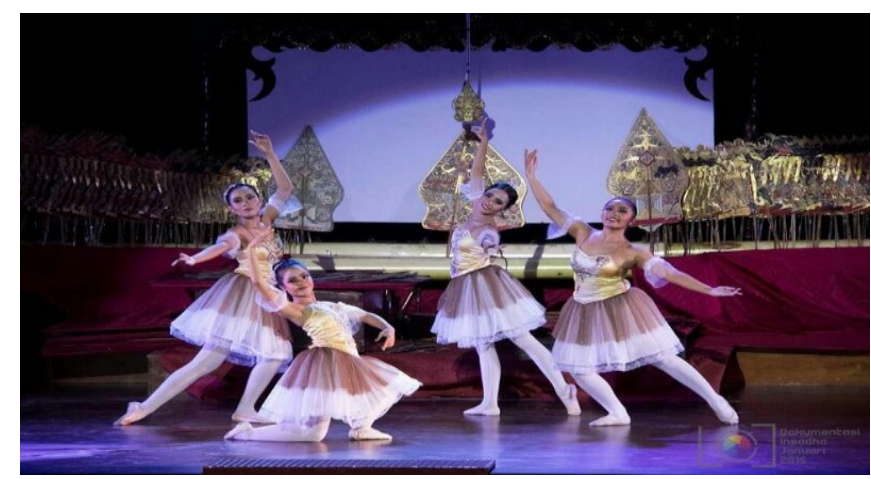

Figure 3: TUTU Club participated in POMDA Cup

Source: Tutu Club

The soccer student organization stood around 2000s and, at that time, was only operating to accommodate students who love playing soccer and train them to participate in POMDA Cup (a selection event for POMNAS soccer teams in D.I.Y contingent). Through this organization students can hone their interest and talent that they possessed so they can become professional soccer players with a lot of achievement and can bring honor to SDU.

In 1993, the art student organization Karawitan was established when USD was still IKIP Sanata Dharma. Karawitan organization has the objective to promote Indonesian art and culture by introducing the art of Wayang Kulit (shadow puppet show), art festival Karawitan Gending Gerejani (Sekar Geni) and other festivals to society in hopes of resuscitating people both inside and outside of campus to realize how rich this country is because Indonesian heritage has its own unique diversity which makes that inheritance highly qualified if it is preserved well.

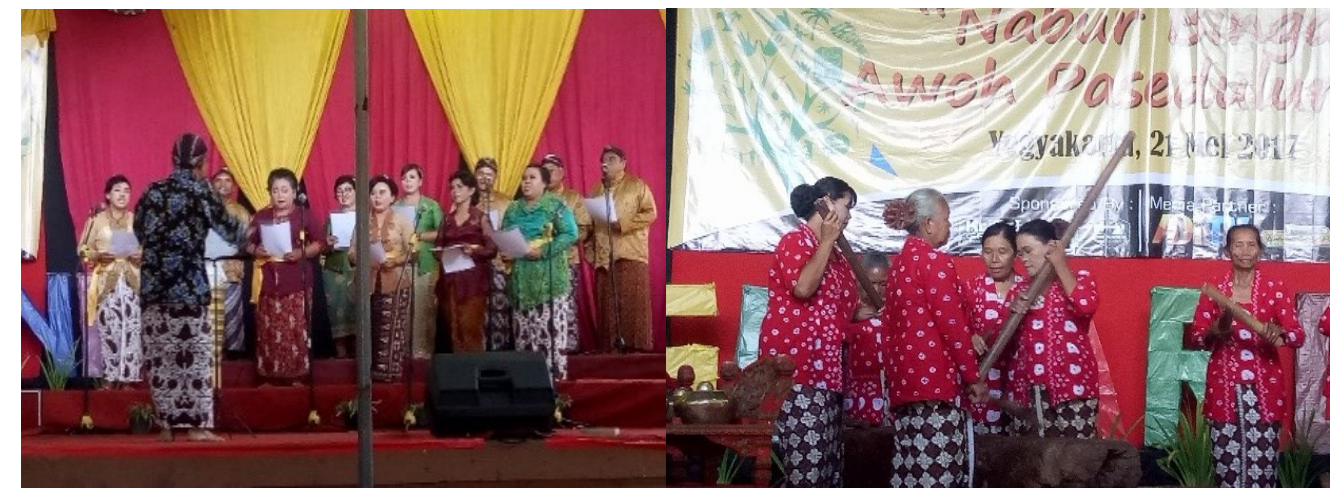

Figure 4: Picture of Sekar Geni Festival in 2017

Source: Karawitan Student Organization

The student organization Student Regiment (Menwa) of SDU stood in May 4, 1985, but it was not yet officially formed. Back then, Menwa organization was 
still under the auspices of Indonesian National Army (TNI) and was not under the auspices of the university. In its development, in 2000 Menwa was officially taken under the university's care. This happened because of reformation and the decision letter (SK) from 3 ministers, The Minister of Defense, The Minister of Education, and The Minister of Sports. So, Menwa organization is managed by university and is led by the rectorate, especially vice rector III. Menwa organization has its roles in various events such as a mass mangrove planting action, the hoisting of The Red and White Flag in National Independence Day which is held in SDU and making sure the Independence Day flag ceremony goes without a hitch, also the role Menwa plays in a blood donor event where Menwa works together with KSR organization to ensure the event that was held in around May 2017 went smoothly.

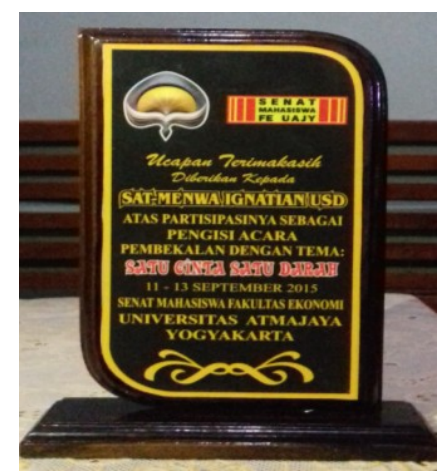

Figure 5: The participation of SAT-MENWA IGNATIAN SDU in a student senate of the Faculty of Economics Atmajaya Yogyakarta University in 2015

Source: MENWA Student Organization

Teater Seriboe Djendela (TSD) is one of the art student organizations in SDU that specialized in the field of theatrical play. Established in May 14, 1999 in Ngobaran Beach, Gunung Kidul, the first members of TSD came from Kethoprak Sadhar Budaya community, one of the first art activist communities to exist in SDU. Experiments of various genres are the result of TSD's interaction with various theater community either with theater communities from other campus or an independent theater community. The interactions are made through a hospitality visit or through the TSD members' individual involvement with other art communities in various projects, such as involvement with Bagong Kussudiarja foundation, Bengkel Mime Theater, Umar Kayam foundation, etc.

Aikido was born in Yogya in 1996, being brought by Haris Martono, the student of Milda Gustiana (Bandung). Haris who was still in kyu-2 later became a trainer and Laddy Lesmana as the first dojo chairman in Yogya, who first had to train in a dojo outside of the city in Semarang. On the initial management, they were helped by Oerip Handoko and Sutoyo. After numerous times of changing their location, in the early September of 1997, by the effort of Andi and Theo, the Dojo of SDU was opened. Therefore, the Sanata Dharma Aikido Dojo is the oldest aikido dojo in Yogyakarta. The contribution of Aikido in the development of students' soft skills is to gain harmony with one self and their environment in 
the form of martial arts in accordance with the philosophy and teaching of O'sensei Morihei Ueshiba as well as producing a qualified trainer (sensei) who can pass on aikido in accordance to O'sensei's teaching.

In 2007, the Basketball Student Organization was recently established as a student organization in SDU. In 2008, SDU's women team gained the first rank in Yogya and was set to represent Yogyakarta in the national league. Through those activities, students become more responsible in managing their activities both in campus and in basketball community, they become more disciplined, have higher sportsmanship in participating in the competitions, and it improves student's cooperation in reaching the common goal.

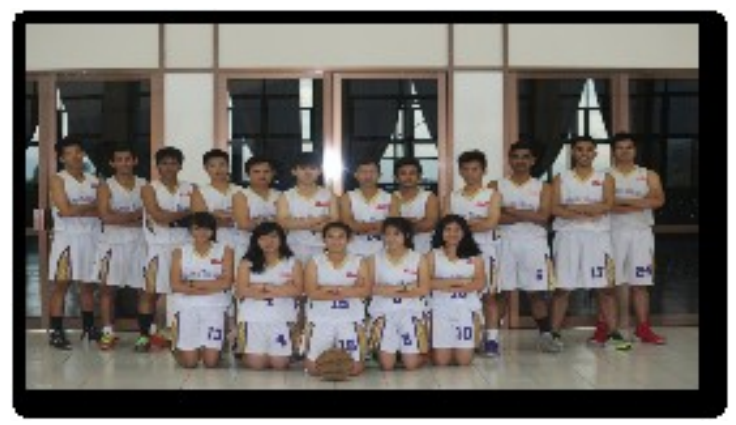

Figure 6: Documentation of Basketball Organization Team

Source: Basketball Student Organization

In May 25, 1971, INKAI was officially established as an institution member of FORKI and by PB FORKI, INKAI was chosen to represent Indonesia. The vision of INKAI organization isto shape karate who master not only the martial arts technique but also the value inside and are able to align themselves with the spirit of 3C (Competence, Conscience, Compassion). The objective of INKAI is to build students' soft skills to ; 1) become a place to develop students' potential; 2) to raise the flag of Sanata Dharma through Karate; 3) to shape an individual with integrity; 4) to shape a tough individual; 5) to shape a humble individual with etiquette.
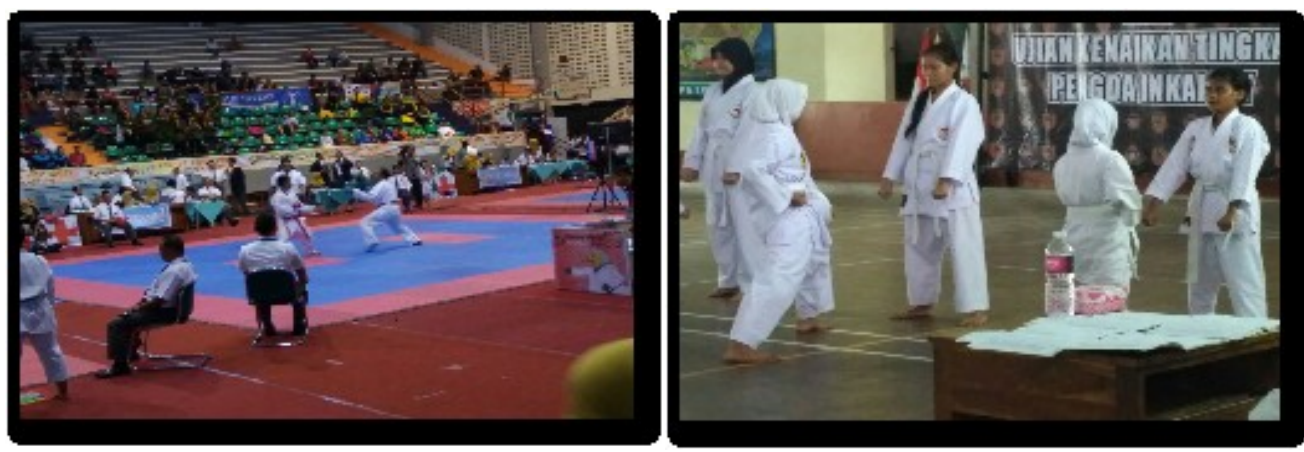

Figure 7: Photos of INKAI organization activities

Source : INKAI Student Organization 
Shorinji Kempo of SDU has been around since 1992 founded by the late Dr. Christina Siwi Hkitayani. Shorinji Kempo organization of SDU was initially named Kempo organization, but because there were changes in AD/ART PERKEMI (Shorinji Kempo Indonesia Brotherhood). Then the name was changed. The contribution of Kempo organization in SDU students' personality development is to create kenshi students that care about society, have high discipline, and are dignified through mental and physical development as well as becoming a martial arts organization that has national level achievement.

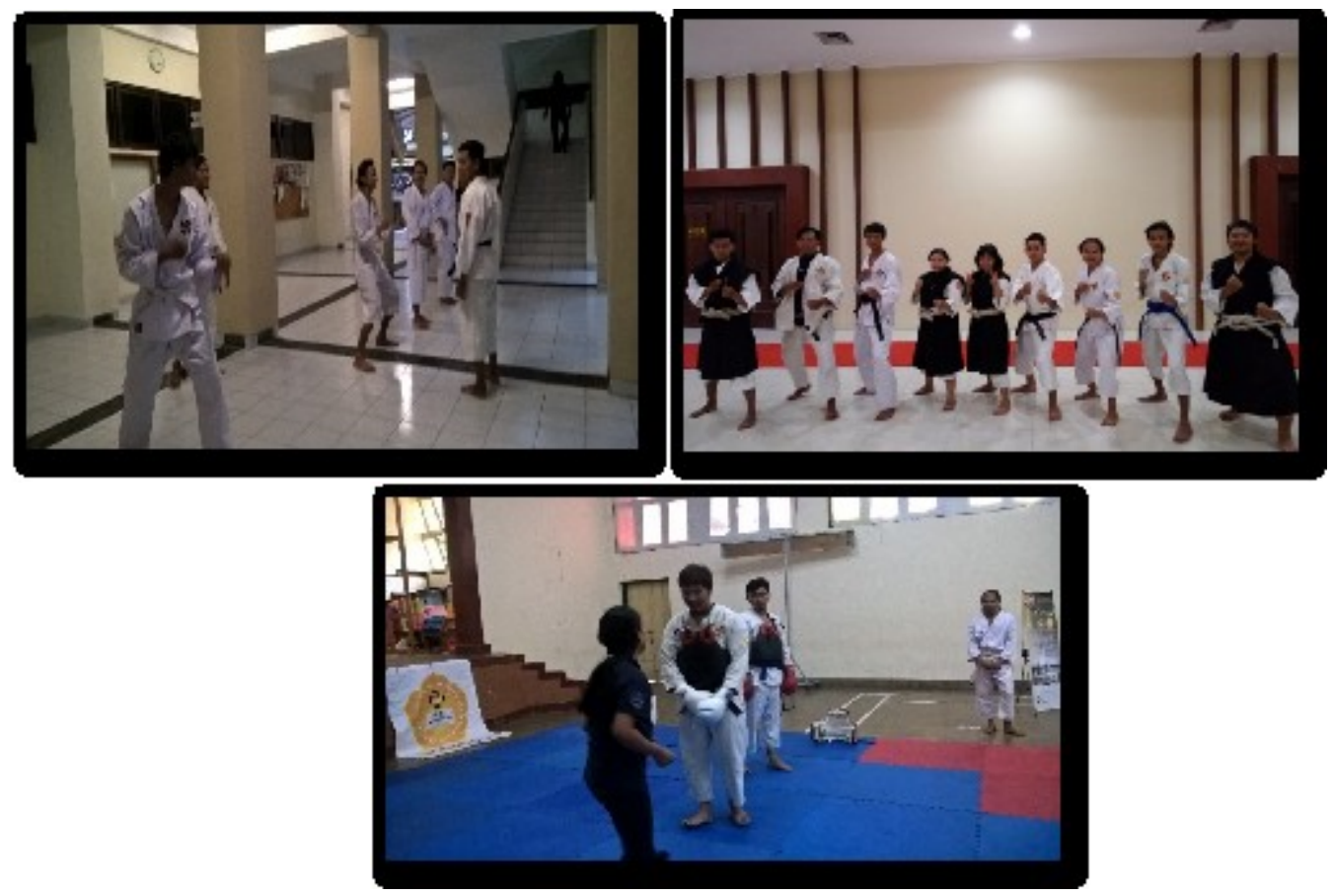

Figure 8: Photos of Kempo organization activities

Source: Kempo Student Organization

SDU Taekwondo was first held in Tuesday, August 25, 1987 by Sabeum Nim Ir. Didi S. Margono. Sabeum Nim Ir. Didi S. Margono was the first trainer of SDU Taekwondo group until the present time. Taekwondo besides improving one's soft skills also give someone a martial arts training that is useful to protect themselves from every threat especially physical threats. SDU Taekwondo organization participated in KEJURNAS 2015, "Taekwondo National Open Championship".

SDU student organizations that aim to improve oneself with knowledge as well as socializing are Natas Organization, KSR, and Community Service Organization.

UKPM (Student's Press Activities Student Organization) Natas was established in the 80s (but Natas AD/ART that we have managed to found was signed November 1, 1993). This organization domiciled in SDU Yogyakarta. At that time, there were a lot of students who liked to hold a discussion on intracampus problems as well as nation-wide polemics. They raised a lot of issues and 
it felt necessary that the general public had to know. The only way was to write the things they had discussed in an alternative media in the form of bulletin.

KSR Student Organization was inaugurated on September 22, 1986. The vision of this organization is to combine the principles of cooperation with qualified student resources that uphold honesty, fairness, piety, and entrepreneurial spirit.

In its development, KOPMA Student Organization is a place to develop students' creativity which is expected to be able to give benefits to students in self - development so that when they are trusted into the working environment, they have prior experience and the ability to work in teams.

From the beginning of its foundation in 2000 until 2006, Community Service Student Organization experience development every year. Based on Community Service Chairman Agus wahid Santoso the most significant development in his time in Community Service organization can be seen in 2014 2015, it can be seen through the teamwork they did. Community Service organization was invited by Vice Rector 3 to give a presentation about the work program of Community Service organization in front of Students from Sogang Korea. In the field of education, the members of Community Service organization become volunteers to teach in community schools. The organization works with two community schools: Kampung Juminahan Community School and Kampung Jogoyudan community school. Other than that, Community Service organization works together with Kemetiran Church and SDU LPPM to develop SAMBEL (Sanggar Maria Belajar).

SDU Student Organization that can train public speaking and vocals are Masdha Student Organization and Students' Choir Cantus Firmus (CF) Student Organization.

In October 15, 1990 a community radio student organization : Masdha Radio was formed. The idea behind the name of the radio itself came from the abbreviation of Sanata Dharma Students (Mahasiswa Sanata Dharma) that became "Masdha". Of course as a community, this radio organization becomes a place where students can give their ideas. The organization's visions that also help in building SDU students character are to maintain a comfortable familial atmosphere for all crew members, do an internal fix of Masdha and develop each division job description, to establish collaboration with other student organizations and a few work partners outside of campus, and to increase monthly profit.

Students Choir "Cantus Firmus" was first founded in 1981 as a church choir with the name Driyarkara. Then this choir evolved into a public choir in 1991, and was in the sub unit of art organization. After getting a lot of achievement in October 20, 1998, this choir was established as an official Student Organization in SDU Yogyakarta and at that exact date, Students Choir Cantus Firmus' birth and the birthday was settled. The contribution of Students Choir Cantus Firmus students organization in the development of students character are : improving self - discipline through routine training that is held every evening plus additional training when the time of a competition is near, increasing responsibility through a lot of long and rigorous training, improving individual's ability to do better in daily time management between daily activities, campus activities, and vocal trainings, improving individual's vocal ability and quality. 


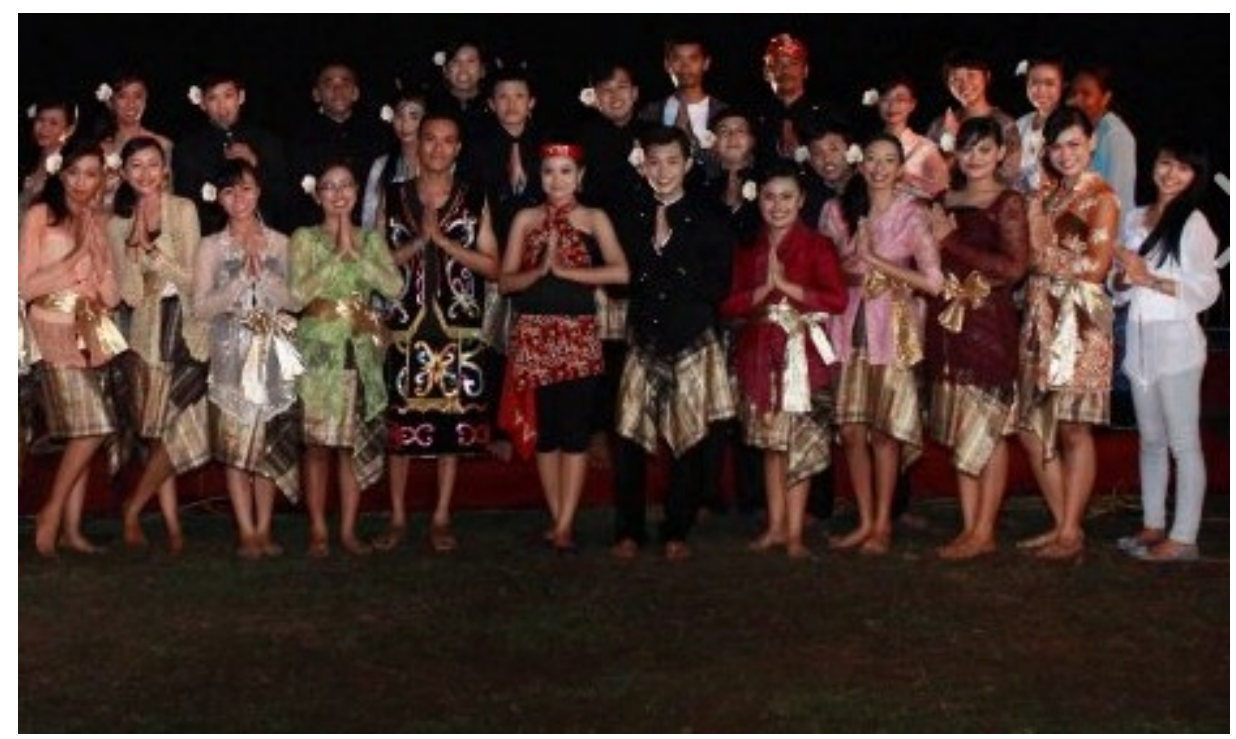

Figure 9: Harmony of Indonesia Concert

Source: Private Document

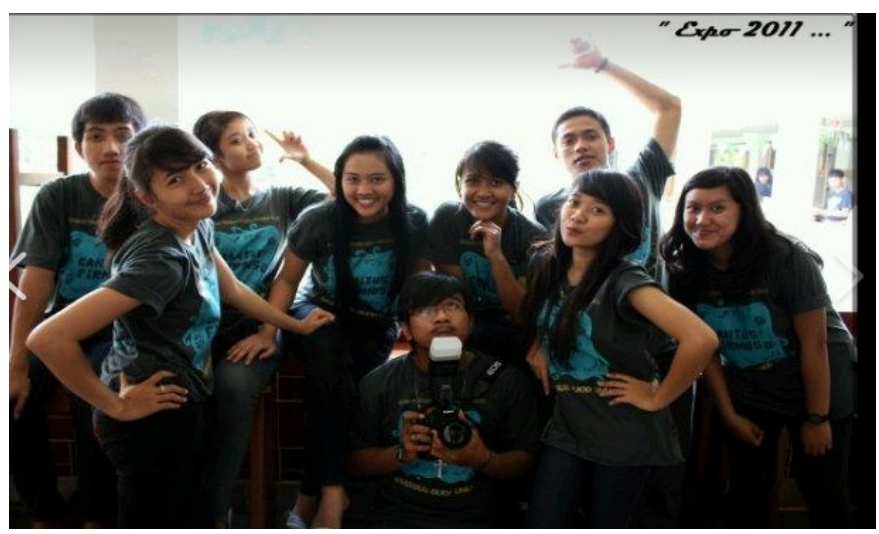

Figure 10: Expo 2011

Source: Students Choir Cantus Firmus

A couple of student organization documents are needed as a proof of students' creativity development and the progress of SDU. But, until now the records have not been tracked. From the research that has been done in order to finish this article, it proves that SDU needs to give their attention seriously in order to support students character other paying attention to only their academic struggle. In accordance with Driyarkara's mission which is "Humanizing young human" this article presents the track records of SDU student organizations, that exist to open our minds so that we can create Young Driyarkara Generation and lead the University to be ready to meet every challenges.

\section{Conclusion}

The result of the research managed to trace the student organizations' track records and from the data gathered, there are 19 student organizations which manage their documentations well. Those student organizations are ; (1) Grishada, (2) Lens Club, (3) Mapasadha (4) Masdha, (5) Tutu Club, (6) Soccer, (7) 
Karawitan, (8) Menwa, (9) Natas, (10) Community Service, (11) Teater Sanata Dharma (TSD), (12) Students Cooperation (KOPMA), (13) Aikido, (14) Basketball, (15) INKAI, (16) KEMPO, (17) Voluntary Corps (KSR), (18) Students Choir Cantus Firmus, (19) Taekwondo. Some others have the dynamics in their developments but still remain standing until today.

\section{References}

Driyarkara, N. (1980). Driyarkara tentang manusia. Yayasan Kanisius: Yogyakarta.

Elfindri. (2011). Soft skills untuk pendidikan. Baduose Media.

Goleman, D. (2003). Kepemimpinan yang mendatangkan hasil ( $1^{\text {st }}$ ed.). Yogyakarta: Amara Books.

Lestari, T. (2014). Efektivitas teknik pelatihan melalui penghayatan pengalaman (experiental learning) terhadap peningkatan kohesivitas kelompok kerja unit kegiatan mahasiswa. Retrieved from http://repository.upi.edu/7171/

Mulyono, I. (2011). Dari karya tulis ilmiah sampai dengan soft skills. Bandung: Yrama Widya.

Munandar, U. (1985). Mengembangkan bakat dan kreativitas anak sekolah. Jakarta: Grasindo Jakarta.

Putra, I.S. \& Pratiwi, A. (2005). Sukses dengan soft skiils. Bandung: Univ. Teknologi Bandung.

Sailah, I. (2008). Pengembangan soft skills di perguruan tinggi. Jakarta: Direktorat Jenderal Pendidikan Tinggi.

Zulkarnain. (2002). Kretativitas dan kontrol diri. Yogyakarta: Ilmu Cendekia 